\title{
ENGLISH LEARNING DIFFICULTIES FACED by SANTRI in ISLAMIC BOARDING SCHOOL: AN ANALYSIS
}

\author{
Umar \\ STIT Buntet Pesantren Cirebon \\ aangumar80@gmail.com \\ Umar. (2021). Analysis of English Learning difficulties for college students who actually are santri. \\ Journal of English Language and literature, 6 (2), 51-58. DOI 10.37110/jell.v6i02.124
}

\begin{abstract}
This case study intended to analyze the higher graders' English learning difficulties of the Islamic Education Guidance and Counselling study program and Islamic Education Management. This study mainly focused on finding students' difficulties in mastering English competency. It was conducted in Sekolah Tinggi Ilmu Tarbiyah (STIT) Buntet Pesantren Cirebon by involving 40 students who are also as Santri and a lecturer as the subjects or the researcher. The researcher used both classical and individual approaches in gathering both qualitative and quantitative data. The procedures used context, input, process, and product/CIPP-Evaluations Model for its benefit to increase teaching quality. The data was analyzed by using McDonough \& McDonough Model, i.e.: (1) exploration on both students' learning processes and the results; (2) analyzing the results of exploration through questionnaire, interviewing with students; (3) conducting peer-debriefing, i.e. interviewing with other lecturers related to, the methods, syllabus content, whether they have matched with the students' needs. The findings showed that students' English learning difficulties for: (1) Their sense of being-forced; (2) Low mastery on the basic concept/intakes; (3) Less-endorsement from their environment; (4) Forget factor; (5) Having lesschance to practice. In reference with the findings, it was suggested that teachers and institution should facilitate and give high motivation for their students' English learning process.
\end{abstract}

Keywords: English Learning, Learning Difficulties, College Students, Santri

\section{INTRODUCTION}

A college student is a term for someone who is taking or undergoing higher education at a college such as Sekolah Tinggi, academy, Institute and the most common is university. Historically, students from various countries have played an important role in the history of a country. For example, hundreds of students succeeded in urging President Suharto to resign from his position as President, in Indonesia in May 1998.

A college student is a person who studies in college either at a university, institute or academy. Those who are registered as students in colleges can be called college students. But basically, the meaning of college student is not that simple. Being registered as a student at a university is only an administrative requirement to be a student, but being a student contains a broader understanding than just the administrative problem itself. Student affairs, comes from the sub word student. As we know, college students are divided into two words, namely college and students.

Indeed, the main task of a college student is to study, complete his coursework and become a more mature and mature person. Ready to work for the country. Apart from all that, it turns out that college students cannot be interpreted as mediocre. In fact, thanks to college students, many major events have become historical records because of the college students.

College students are also touted as agents of change in life, as the next generation, college student actions on a large scale are effective in 
influencing political change, college students indirectly as cadres of the nation's successors. Not many know that the role of college students in the history of the struggle of the Indonesian nation was first initiated by Budi Utomo on May 20, 1908, which marked the rise of the nation's youth. Not only that, on October 28, 1928, had college students played a significant role in the process of forming the Unitary State of the Republic of Indonesia in the framework of the Youth Pledge. As for the role of college students on Indonesia's Independence Day, it turns out that college students participated in helping in the formation of Indonesian independence.

College students also act as movers who invite the whole community to be able to move in making changes for the better, taking into account the various knowledge, ideas, and knowledge they have. It is no longer the time for college students to be silent and also not concerned with the problems of the nation and their country, because it is on their shoulders (college students) that the point of revival of a country or nation is placed.

College students have extraordinary power when they are united in one unit. College students do not just study and seek knowledge. In fact, the students in 1998 were also able to overthrow the new order and escort it into the reformation period. In other words, college students are pioneers in the struggle and development of the nation which may not be realized and understood by the general public, even new college students.

Meanwhile, According to Zamakhsyari Dhofier, the word pesantren comes from the word santri, with the prefix pe in front and the suffix an meaning the residence of the santri. According to John E. The word "santri" comes from the Tamil language, which means teacher of the Al-Quran.

According to the KBBI online, Santri has two meanings: First, a santri is someone who tries to study Islam seriously; and second, someone who worships sincerely. The word santri comes from the word "cantrik" which means someone who always follows the teacher where the teacher goes and stays.

Meanwhile, according to Nurcholish Madjid, the origin of the word "santri", can be seen from two opinions: First, the opinion that "santri" comes from the word "sastri", a word from Sanskrit which means literacy. This opinion, according to Nurcholish Madjid, seems to be based on the santri being a literacy class for Javanese who try to explore religion through books written in Arabic. The second is the opinion that the word santri in Indian means a person who knows the sacred books of Hinduism, or a scholar of Hindu scriptures. Or in general it can be interpreted sacred books, religious books, or books about science.

From these various views, it seems that the word santri which is understood today is closer to the meaning of "cantrik", which means someone who studies religion (Islam) and always faithfully follows the teacher where the teacher goes and stays. Without the existence of students who want to settle down and follow the teacher, it is impossible to build a hut or dormitory where the students live and later called Pondok Pesantren. Based on the above understanding, it can be concluded that the santri is someone who is learning to deepen knowledge about the Islamic religion seriously.

According to sources that have been obtained previously from this research that the college students in the STIT Buntet Pesantren consist of two groups, namely the Santri Mukim and the Santri Kalong, where the explanation is as follows:

Santri Mukim are students who come from faraway areas and live in Pondok Pesantren. The santri mukim who have lived the longest in the pondok pesantren are usually a separate group with the responsibility for taking care of their interests. They also bear the responsibility of leading young students' activities in Islamic boarding schools or Pondok Pesantren.

Santri Kalong are students who come from villages around the pondok pesantren, who usually do not live nor sleep in the pondok pesantren. To follow their lessons at the pondok pesantren, they commute from their own homes. Usually the differences between large and small pondok pesantren can be seen from the composition of the santri kalong. The bigger the pondok pesantren, the greater the number of santri mukim. In other 
words, small pesantren will have more santri kalong than their santri mukim.

From the various understandings above about college students and santri, it can be concluded that santri and college students are college students who live in Islamic boarding schools or pondok pesantren and these students have two learning activities, namely studying in college as a prospective academic / person who is active in academia and also studying at Islamic boarding schools or pondok pesantren, where these santri students have the responsibility to be able to run two activities together to gain more knowledge.

There are still many difficulties in learning English experienced by students, especially in private universities. English is often a "scourge" for college students or Santri. The first reason that is most often put forward is because English is not a "mother" language so it is difficult to pronounce the English words. The second reason is the difficulties to practice compiling English vocabulary so that it makes better English sentences so that they can be understood well.

This second reason is actually a provision for how to teach English in class so that college students who are also santri are proficient in English. English courses at universities in Indonesia are generally grouped into General Basic Courses that must be followed by college students.

The purpose of this course is to equip students with active communication skills in English, namely the ability to listen, speak, read and write. As a compulsory subject, English is delivered in the form of general courses where the delivery method is in the form of lectures, discussions, group work and direct language practice.

English Language Teaching (ELT) based on the needs and interests of students is generally grouped into two, namely General English and special English (English for Specific Purposes or it is usually called ESP). General English studies about four skills of English (Speaking, Listening, Reading and Writing) with general topics while ESP studies English based on the profession of work or the specific needs of students such as economics, religion, biology, education, social and health. (STIT) Buntet Pesantren Cirebon has so far contained general English material (general English).

The material is taken from books or English textbooks published from within and outside the country. Topics or themes in textbooks are mostly about general things such as how to introduce oneself, tell about family, and tell about things or activities that have been done and so on.

Initial observations show that their English intakes are very low. In fact, the quality of the input will certainly affect both the process and learning outcomes. The quality of intakes of Sekolah Tinggi is the output of the level of education in senior high schools.

In addition, the frequency of learning in Sekolah Tinggi is also less supportive of improving the quality of English learning. English is generally only given in 2 semesters, with a frequency of 2 Semester Credit Units (SKS) per week. The time for learning English is relatively disproportionate to the needs of students, moreover English is one of the keys to overcome various problems of graduates in the future, where the competition is getting tougher. Mastery of English is also a mean to boost Indonesia's human resources, which according to the Human Development Index is the lowest category in Asia.

What makes it worse are students who have two busy learning goals because they are students in college and at the same time as santri who learn about religion which have significant differences in learning materials.

Global competition in all fields demands quality improvement human resources (HR) including lecturers, as the spearhead. Campus output must be of high quality in order to be competitive and have a high bargaining position. One of the efforts to realize the above is to improve the quality of learning English. Mastery of English will open their horizons to the development of science and technology, including education which is currently easily accessible from various sources.

Improving the quality of learning English can be achieved if the background of learning difficulties is known. Information about learning difficulties can be used as a basis for determining goals, methods, strategies, and learning materials 
that are relevant to the needs of graduates. For this reason, it is necessary to study the background of learning difficulties in English. This study involved students of BKPI and MPI of the Faculty of Education, Tarbiyah College of Sciences (STIT) Buntet Pesantren Cirebon, who incidentally were prospective teachers.

Based on intensive observations made by author at the beginning of the semester, there are indications that the quality of students' English mastery is very low. Most of the lecturers' expressions and instructions using the most basic English are difficult for most students to understand, including difficulties in developing English competence. Their language skills of reading, listening, speaking, and writing are at the elementary level. In fact, they have studied English for 12 semesters at school. Based on this phenomenon, the author analyzes students' learning difficulties in English, which can then be used as a basis for improving the quality of learning.

The learning difficulties of students who are also Santri are based on: (1) learning motivation; (2) English intakes, (3) the role of lecturers and students in learning, (4) infrastructure, (5) learning materials, and (6) learning environment. These six domains are the variables of the research study.

As a basis for the study, the author refers to several relevant theories and previous research results. The theoretical reference concerns various concepts of learning motivation, learning English, the role of lecturers and students in learning, standardized English learning facilities / infrastructure, learning materials, and an ideal learning environment.

Motivation is a simple word to say but it is hard to define. Motivation is considered as important aspect to do certain activities in order to be success. Almost all works done requires motivation as activator and encouragement in doing the best effort, one of them is studying foreign language. When a student is motivated in learning English, he/she will make the best effort to achieve it. He/she will try to master in English in any way. On the contrary, if a student is not motivated in learning English, he/she will not pay

any attention of it or even does not care about it at all. Therefore, motivation is considered as essential element together with capacity to achieve success in learning the target language.

To understand what motivation is, it is important to know the definition of motivation, types, sources and roles of motivation. There are some definitions related to motivation from several psychologists. The word motivation is derived from word motive that means anything that encourages person to act to do something.

Etymologically, Winardi (2002:1) explains the term motivation (motivation) comes from the Latin word, namely movere which means to move (to move). Absorbed in English as motivation means giving motives, generating motives or things that give rise to encouragement or circumstances that cause encouragement. Furthermore, Winardi (2002:33) suggests, a person's motivation depends on the strength of his motives. Based on this, the discussion about motivation cannot be separated from the concept of motive. In essence, it can be said that the motive is the cause of the action.

Steiner as quoted by Hasibuan (2003:95) suggests that the motive is "a driving force from within to act or move directly or lead to the ultimate goal.

Based on the description above, the concept of motive contains the meanings (1) motive is the driving force from within the individual, (2) motive is the cause of activity, and (3) motive is directed to achieve certain goals. Thus the motive can be defined as the driving force from within the individual as the cause of activity, which is directed to achieve certain goals.

There are two types of motivation, namely intrinsic and extrinsic. Intrinsic motivation is an urge to do something without coercion (reinforcement) and rewards (rewards) from anyone. Extrinsic motivation is the urge to do something depending on the rewards. If a person realizes that he has intrinsic motivation, rewards can have a negative effect on his performance (Gage \& Berliner, 1984: 412-441).

\section{Method}


This single case study research involves 50 college students of STIT Buntet Pesantren who are also Santri who live in a boarding school around STIT Buntet Pesantren.

Case study is a qualitative research strategy to empirically investigate a various case related to the relationship between phenomena in real life contexts, when the boundaries between the two are not clear.

Case study is an attempt to explain a / various decisions involve: why (why) a case occurs and is investigated, how it is implemented (how to implement), and what the results are (what is the result / what are the results).

Case Studies have four characteristics, namely (1) case studies of phenomena; (2) an indepth study of a/various cases; (3) natural study of a/various phenomena; and (4) an emic/empirical perspective study of a / various cases faced by research participants (Gall, 2003: 435-436). The results of this case studies can then be used as the basis for improving the quality of teaching of the lecturers concerned, which leads to improve the quality of outputs and outcomes.

As an illustration, the following research steps are presented using Model Context, Inputs, Process, and Product, Selection of Focus (Context), Collection of Qualitative Data (Input), Inclusive Case Categorization Data Analysis (Process), Analysis Results Validation formulation of English Learning Policy (Product).

The credibility (trust worthiness) of the results of this study was tested through the validity of the actual learning process in the English class, tri-angulation of theories and data sources that were selected inclusively based on phenomenal problems that emerged during the learning process (Gall, 2003: 591). The data collection uses the following instruments: (1) researchers as data collectors; (2) observation of the learning process; (3) open questionnaire (related to student intakes); (4) document in the form of formative test results, midterm tests, and final exams; (5) in-depth interviews with students, especially those who have problems in the process of learning English while studying at STIT Buntet Pesantren, Cirebon.

The data collected was categorized according to the study variables, analyzed using a content analysis model (analyzing the results of questionnaires, interviews, and tests), and validated using theoretical triangulation techniques, data sources and peer debriefing (validation through sources that have never been studied). The questionnaire data is in the form of informants' answers regarding: learning motivation, intakes, the role of lecturers and students in learning, available infrastructure, learning materials, and their learning environment. All data are sorted and categorized into: (1) Low motivated with Low-achievement, (2) Wellmotivated with Low achievement, (3) Stabilizedprogress with Stable-achievement, Progressive-experience with Significantachievement which is codified into evenly and significantly progress. The following presents the results of the study as well as a discussion of each of the findings variables.

\section{Findings and Discussions}

\section{Low-motivated with Low-achievement Category}

Low-motivated with Low-achievement includes the expression of the answers of 15 students, which in essence are as follows; (1) They do not study hard because of boredom during learning English; (2) English in STIT Buntet Pesantren is too short, there are only 2 credits; (3) In STIT Buntet Pesantren, Students' interest in learning increase but they still cannot communicate to one another in English; (4) Since studying in high school, they are not interested in learning English because they are forced to study English for various reasons, while English Teachers at school do not understand yet the interests of each student; (5) The language in STIT Buntet Pesantren is better but they have no enough time to study English seriously because of reason number (2).

This category consists of three subjects with low motivation, with low learning outcomes. Based on their expressions, it appears that they really don't like English because they don't realize its benefits. It is certain that they don't like learning English, nor learn any material, because actually they don't intend to go to college. Logically, smart students are progressive and certainly realize the 
importance of learning any materials, including English.

This finding does not need to be developed or investigated further because it is very difficult to develop people who do not have self-awareness and self-esteem. This fact is in line with the Gestalt theory (in Woolfolk, 1984) that the learning process requires a unified aspect of thinking, remembering, and self-awareness. Like the systemic form of the body, each member of the system cannot stand alone. If the limbs are scattered, the body will die or at least not function optimally. Likewise with one's awareness in learning.

\section{Well-motivated with Low-achievement Category}

The second category includes 16 students, namely the Well-motivated with Low-achievement group. The following is a snippet of the data: (1) There are students who are very interested and happy to learn English because they think English is important to face the era of globalization; (2) There are students who are motivated to learn English because not only from having a good English lecturer at STIT Buntet Pesantren, but also they have interesting experiences, namely wanting to appear in public through an English speech competition, even though they are not fluent in speaking; (3) There are students who think that the performance of the English lecturer is good, but they think that they have too many things to do at STIT Buntet Pesantren and also at their boarding school; (4) In learning English at STIT Buntet Pesantren, there are students who feel that there has been no significant improvement because apart from not being a major, they are overloaded with assignments from other courses, and there are no friends to practice outside of class; (5) There are students who want to be able to speak in English but according to him, some of the students often get tasks from their Kiai or join other activities so that some students are often truant; (6) There are students who think that English lecturers are good, have a lot of humor so that they are not bored and in their lectures they are often given dialogue tasks to memorize, thus increasing their vocabulary a lot; but they feel that there has been no improvement in learning outcomes, even though they really want to improve them; (7) There are students who really like English because in addition to English lecturer is very interesting in teaching English, so it is easy to understand, the students also realize that mastery of English can make it easier for people to find work; (8) There are students who enjoy studying English because apart from being disciplined and humorous lecturer, he is also good at explaining. However, there are things that students don't like, namely the class schedule is too short.

There are 6 informants that fall into this category. Based on their written expressions, it can be concluded that they are actually interested in learning English. Their low absorption and learning outcomes are not caused by their low interest in learning, but because of limited initial abilities that are less favorable. Those unfavorable initial abilities some are caused by overloaded assignment factors and human factors that called 'forgetting'.

The above two factors make them very slow in responding to the lecturer's stimulus. According to the concept of Behaviorism, an unpleasant learning experience will have an impact on the process of getting the next insight. In fact, mastery of English is a process of conditioning or habituation that should not be interrupted, because language is a habit. If the conditioning is interrupted, the consequence is to repeat the concept / theory from the ground up to restore the past memory that has been piled up by new insights. The concept of repetition in this research is done by providing material that weighs the same difficulty as English material in high school. However, to restore enthusiasm and improve the achievement of this category of student groups, it is necessary to support the availability of a relatively long time. The problem is the limited time available so that the results are relatively not optimal.

\section{Stabilized-progress with Stable- achievement Category}

The Stabilized-progress with Stable-achievement category includes 14 students. Almost all 
expressions in this data category have a good impression and motivation about learning English, since they are in high school until they are at STIT Buntet Pesantren. The following are excerpts from their experience in learning English: (1) There are students who are actually very interested in learning English if the supporting factors really exist, the teacher is able to motivate students and be creative; (2) There are students who feel that the English lecturer is less assertive so that college students are less motivated to learn; (3) There are students who think that the increase in interest in learning depends on the willingness and ability of each student - if they have the ability, there must be an increase; (4) At STIT Buntet Pesantren, the majority of students have forgotten English fortunately according to them the English lecturer is quite good and patient because he is able to teach the class in a fun way; (5) There are students who propose that the frequency of learning English should be increased proportionally; (6) There are students who are satisfied with the teaching methods used by the lecturer in STIT Buntet Pesantren because they learn English in fun ways;

The data unit code above contains expressions of students whose motivation and learning outcomes are stable. They are very interested in learning English, not only in universities but since they study in high school. They always have a pleasant experience in learning English, so it is easy to develop their competence, either independently or with the guidance of their English lecturer.

They also have relatively high learning outcomes on average, as indicated by the cumulative results of their formative, midterm and final semester exams (UAS).

\section{Progressive-experience with Significant achievement Category}

The Progressive experience with significant achievement category includes 5 students. This group has a common perception of the experience of learning English, from high school to college. Their common perception is, about the lack of satisfaction in learning English at the time of high school. In fact, they actually have high motivation in learning English.

This data group is the smallest one, most interesting and easy to improve the quality of learning, because they are highly motivated to learn. They also realize the importance of mastering English. However, due to the lack of external supporting facilities, such as: the unavailability of a language laboratory, inadequate tools and subject matter, and so on, this group became a little less enthusiastic about learning.

\section{CONCLUSIONS}

Based on the findings related to the variable of lecturer professionalism above, it can be interpreted that the allegations about low professionalism of English lecturer is not proven at all. In other words, the low quality of student mastery of STIT Buntet Pesantren is more dominated by the following factors: (1) low intakes of English caused by the low quality of English teachers in senior high schools, (2) relatively low learning motivation shown by the low learning ethic of most students, and (3) the 'forgetting' factor according to Klein (1996: 448) is caused by the accumulation of new memories that interfere with each other in the neural formation of the brain, and the failure to present various linguistic expressions that have been studied for many years.

Based on the findings and the analysis as described above, it can be concluded that the difficulties in learning English for the students of STIT Buntet Pesantren are varied. Various causes of student learning difficulties are as follows: (1) No interest in learning because they do not like learning English (2) Interested in learning English but lack of basic knowledge; (3) Good motivation, good ability, but the environment is not supportive; (4) The motivation is quite good, but 'forgets' the basic concepts that he has learned; and (5) High learning motivation, but too short learning opportunities. The following is an explanation of the five conclusions of learning difficulties.

Based on the conclusions above, the authors suggest: (1) Lecturer and institutions should increase motivation to learn English through various activities to support language practice and provide rewards for diligent students; (2) To base 
the learning program with needs analysis or better known as ESP (English for Special Purpose); (3) Lecturer should be observant in choosing methods that are appropriate to the situation, conditions and learning needs; (4) To increase learning

\section{REFERENCES}

Gage and Berliner. (1984). Educational Psychology. (London: Houghton Mifflin Company), page: 412-441

Gall, M. D. \& Gall, Joyce P. (2003). Educational Research: An Introduction (Seventh Edition). Boston: Pearson Education, Inc. page: 435-436

Hasibuan, M. SP. (2003). Organisasi dan Motivasi Dasar Peningkatan Produktivitas. (Jakarta: Bumi Aksara), page: 95

https://kbbi.web.id/santri; accessed on 08 June 2021 at 03:36 pm

McDonough, J. \& McDonough, S. (1997). Research Methods for English Language Teachers. New York: St.Martin's Press, Inc

Huda, M.N. and Yani, M.T. "Pelanggaran Santri terhadap Peraturan Tata Tertib Pondok Pesantren Tarbiyatut Tholabah Kranji Lamongan", Jurnal Kajian Moral dan opportunities; (5) learning is focused on the practice of using language, not just learning language patterns.

Kewarganegaraan, Vol 02 Nomer 03 Tahun 2015, 740-753, (Surabaya: Fakultas Ilmu Sosial, Universitas Negeri Surabaya, 2015), page: 743 .

Purwanto, N. (2011). Psikologi Pendidikan. (Bandung: PT Remaja Rosda Karya Offset), page: 60

Winardi. (2002). Motivasi dan Pemotivasian dalam Manajemen. (Jakarta: PT Raja Grafindo Persada), page: $1 \& 33$

Woolfolk, A. et al. (1984). Educational Psychology for Teachers. New Jersey: Prentice- Hall Inc.

Yasmadi, (2005). Modernisasi Pesantren, (Ciputat: PT Ciputat Press), page 61

Yin, R. K., (1987). Case Study Research Design and Methods. Beverly Hills, London: Sage Publication.

Zamakhsyari, D. (1977). Tradisi Pesantren Studi Tentang Pandangan Hidup Kyai, (Jombang: LP3ES), page: 51. 